\title{
Intravascular Papillary Endothelial Hyperplasia of the Nasopharynx: A Case Report and Review of the Literature
}

\author{
Su Il Kim, Young Seok Byun, Sung Hwa Dong, and Kun Hee Lee \\ Department of Otorhinolaryngology-Head and Neck Surgery, Kyung Hee University School of Medicine, Seoul, Korea
}

\section{비인강 내 발생한 유두상 혈관내막 증식증 1예}

김수일 · 변영석 · 동성화 · 이건희

경희대학교 의과대학 이비인후-두경부외과학교실

\author{
Received September 24, 2014 \\ Revised November 7, 2014 \\ Accepted November 14, 2014 \\ Address for correspondence \\ Kun Hee Lee, MD, PhD \\ Department of Otorhinolaryngology- \\ Head and Neck Surgery, \\ Kyung Hee University \\ School of Medicine, \\ 892 Dongnam-ro, Gangdong-gu, \\ Seoul 134-727, Korea \\ Tel $+82-2-440-6181$ \\ Fax $+82-2-440-7336$ \\ E-mailnose4u@gmail.com
}

\begin{abstract}
Intravascular papillary endothelial hyperplasia (IPEH) is a rare benign proliferation of intravascular endothelial cells. However, IPEH can be easily mistaken for an angiosarcoma, thus differential diagnosis is very important to avoid over-treatment. We report the case of a 22 -yearold man who presented with small lobulating mass in nasopharynx. Computed tomography showed about $4 \mathrm{~cm}$ homogenous mass in the nasopharynx without extension into soft tissues. Complete surgical excision was done and biopsy during operation showed distended vessels and numerous papillae consist of endothelial cells lining a hyaline core. At follow up, no other complications were observed. Thus we present the case and a review of the literature.
\end{abstract}

Korean J Otorhinolaryngol-Head Neck Surg 2015;58(7):492-6

Key Words Intravascular papillary endothelial hyperplasia · Masson's pseudoangiosarcoma $\cdot$ Nasopharynx.
서 론

유두상 혈관내막 증식증(intravascular papillary endothelial hyperplasia)은 피하 혈관 내 내피 세포의 양성 과형성을 일컫는 말로 전신 어디에서나 발생할 수 있으며 특히 두경부 부위에서 많이 관찰된다. ${ }^{1)}$ 흔한 질환은 아니지만 임상적으로 나 병리학적으로 나타나는 소견이 혈관 육종과 유사하기 때 문에 이를 정확하게 감별하는 것이 치료 방침의 결정에 있어 서 매우 중요하다.

저자는 코골이를 주소로 내원하여 드물게 발생하는 부위 인 비인강 내 유두상 혈관내막 증식증으로 진단받은 환자를 경험하여 이에 대해서 보고하는 바이다.
증 계

28세 남자 환자로 2년 전부터 지속되는 코골이를 주소로 타 병원에 내원하여 시행한 내시경상 비인강의 종괴 소견이 발견되어 의뢰되었다. 병력 청취상 고혈압이나 당뇨, 알레르 기 등 다른 질환은 동반하지 않았으며 양측 코막힘과 목의 이물감을 약 2년 전부터 같이 호소하는 상태였다.

인후두 내시경을 사용하여 관찰한 결과 비강 내에는 특이 소견 발견되지 않았으나 비인두에 약 $2 \times 2 \mathrm{~cm}$ 크기의 울퉁 불퉁한 표면을 갖는 다혈관성 종괴가 발견되었으며(Fig. 1), 구인두 및 하인두와 후두 부위로는 특이 소견이 발견되지 않 았다. 보다 정확한 평가를 위해서 조영 증강된 부비동 전산 화단층촬영을 시행한 결과 혈종으로 의심되는 종괴가 비인 강에서 구인두로 걸쳐 있는 것 외에 주변 조직으로의 침윤이 나 다른 병변 소견은 관찰되지 않았다(Fig. 2). 


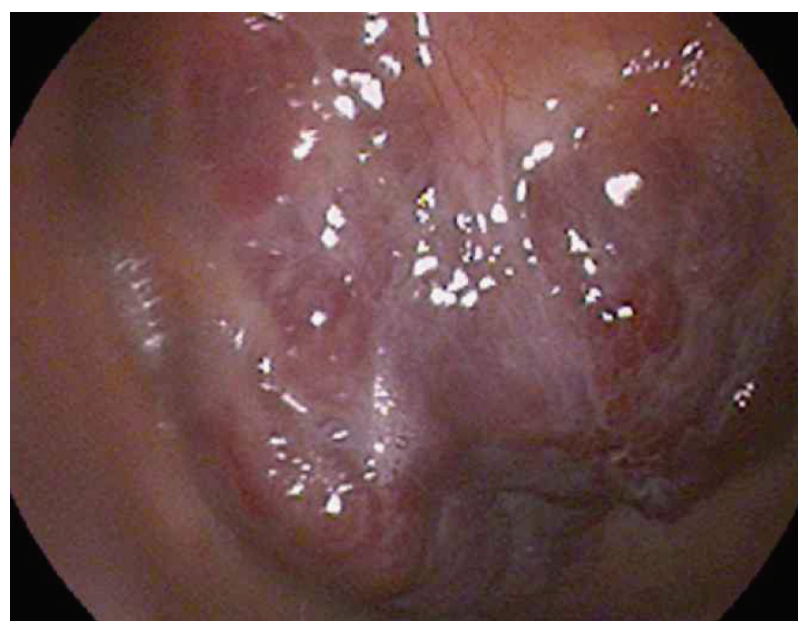

Fig. 1. Fiberscope showing lobulating bluish mass in nasopharynx.
외래에서 straight forcep을 이용한 일부 조직 검사상 약간 의 상피 세포가 발견된 외에 특이 소견 보이지 않아, 혈종 의심 하여 전신마취를 하고 구강을 통해 병변 제거를 시행하였다. 처음에는 비강으로 접근하였으나 병변이 후비강 아래쪽에 위치한 상태로 비강을 통하여 모든 종괴의 제거가 힘든 상태 로 양쪽 비강으로 넬라톤을 삽입하여 구개를 거상함으로써 병변 노출을 용이하게 할 수 있었다(Fig. 3A). 수술 도중 출 혈이 지속될 것을 대비하여 적혈구 농축액을 준비한 뒤 비강 과 구강을 통해서 코블레이터와 흡인 소작기를 이용하여 병 변을 완전히 제거하였다. 약간의 출혈 외에 특이 소견이 없어 수혈은 진행하지 않았으며, 수술 후 출혈을 방지하기 위해 cutan plast, merocel로 비인강을 팩킹하였으며(Fig. 3B), 이 틀 뒤 merocel은 제거하였다.
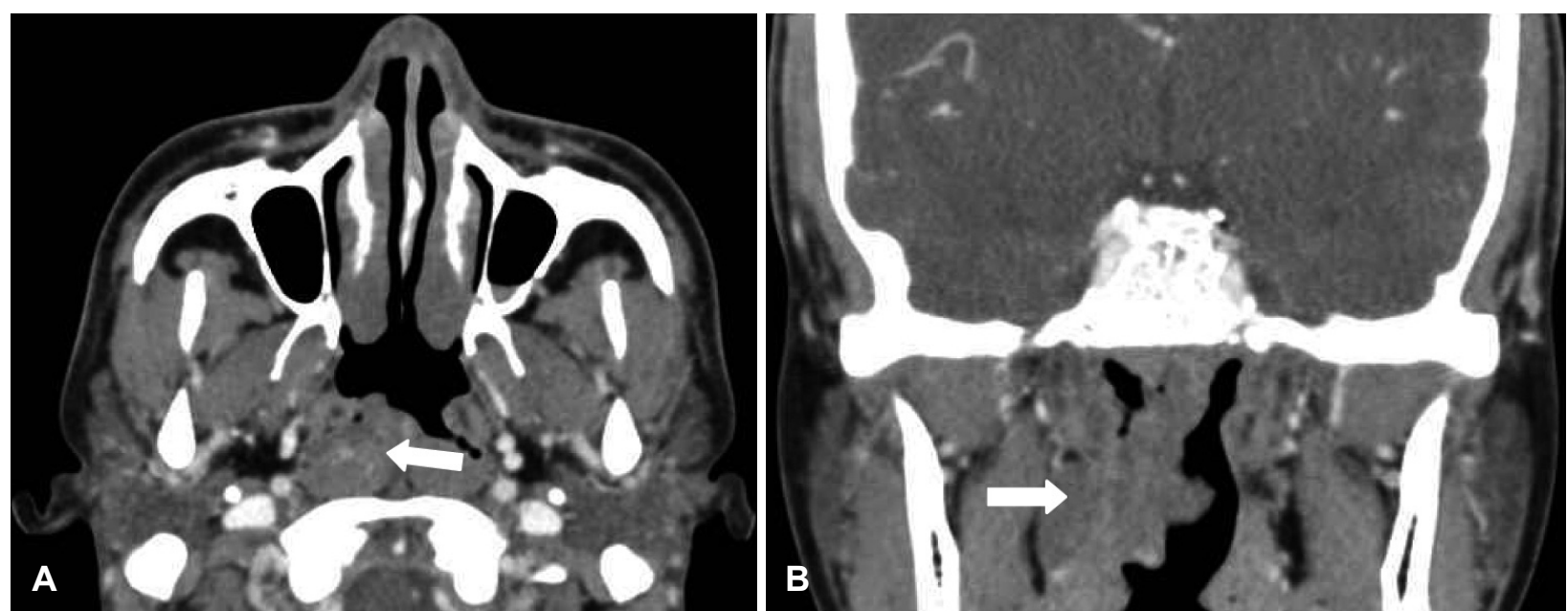

Fig. 2. (A) is axial and (B) is coronal view of enhanced CT scan showing about $4 \mathrm{~cm}$ nasopharyngeal homogenous, lobulating mass (white arrow).
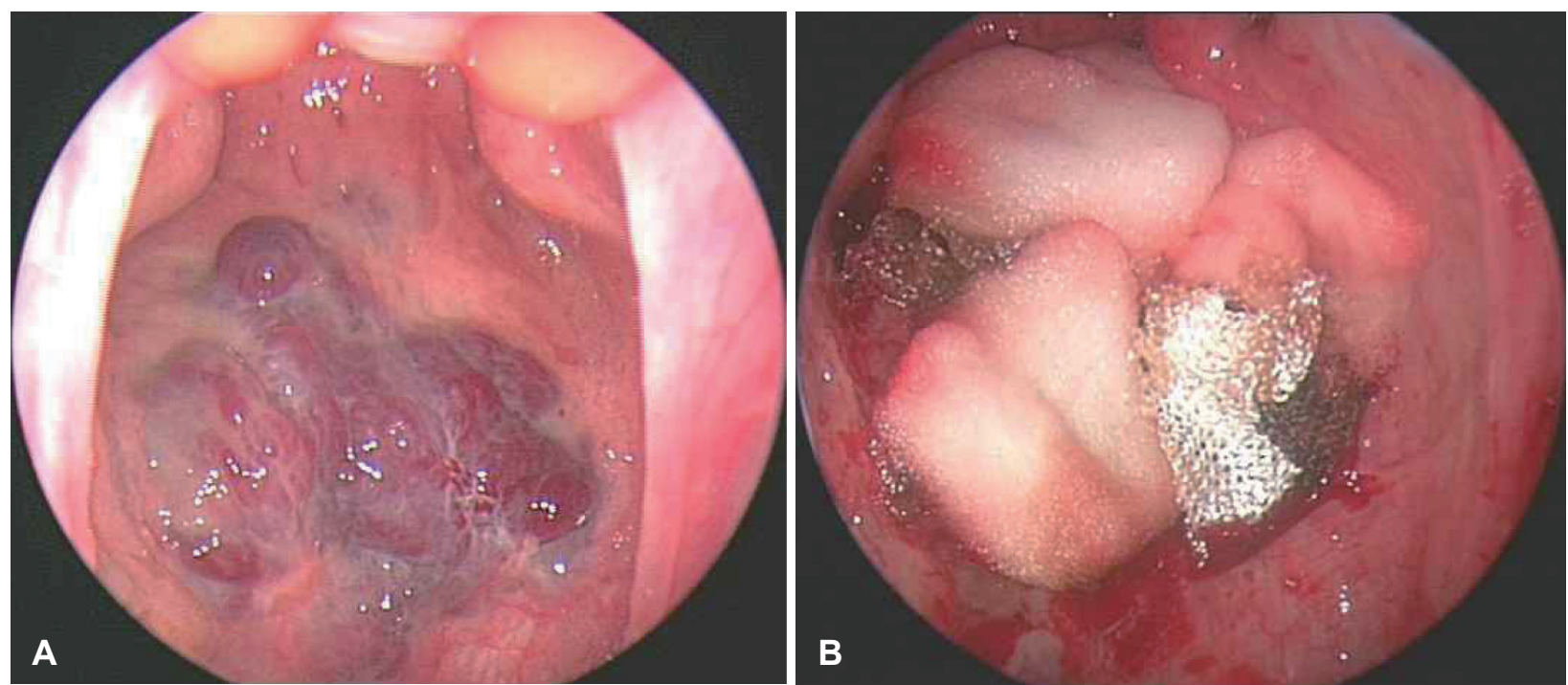

Fig. 3. (A) is well exposed nasopharyngeal mass by using two nelaton catheters into nasal cavity and (B) is packed nasopharyngeal area by tacocom, cutan plast, merocel after excision of mass. 

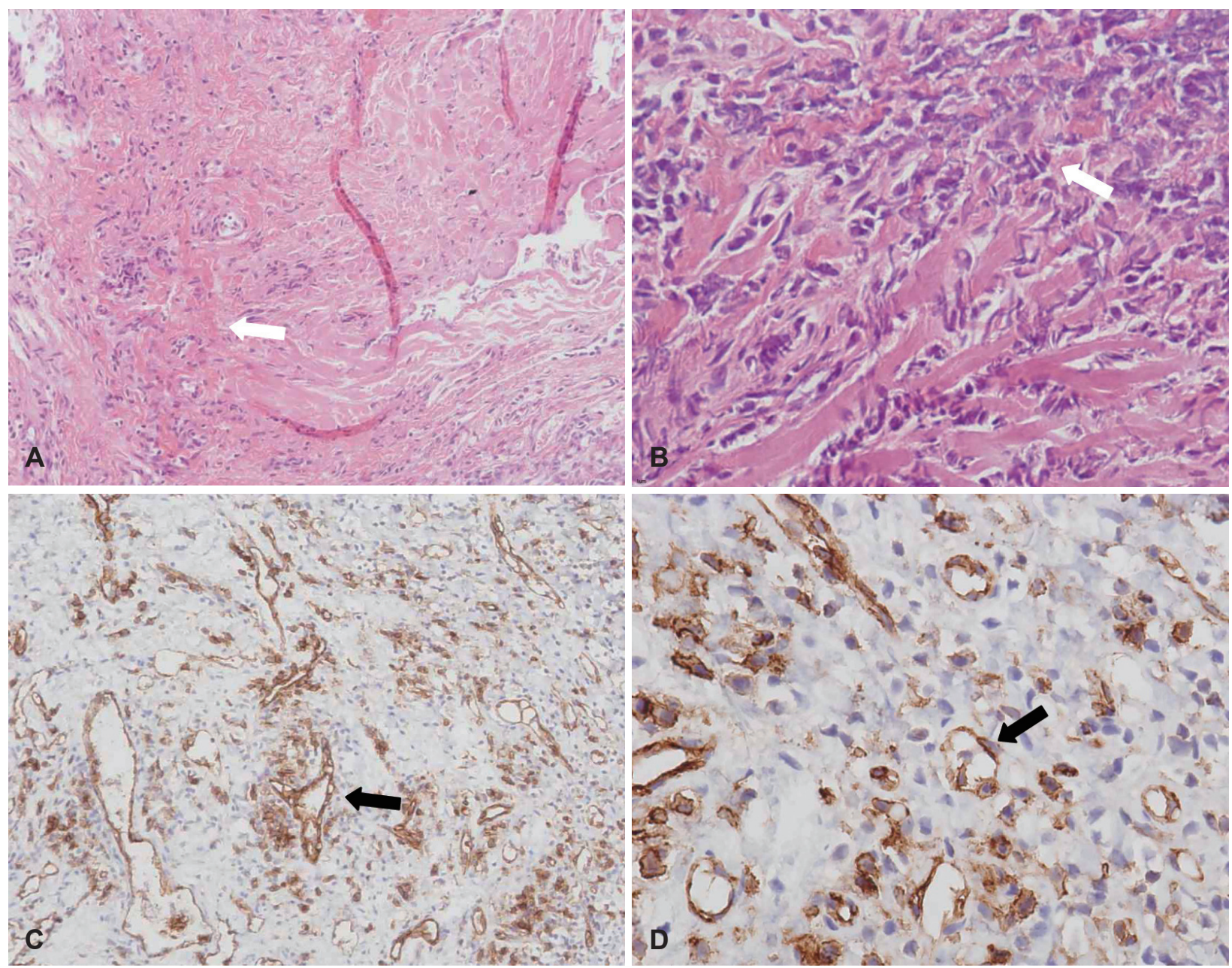

Fig. 4. Histopathology and immunochemistry showing intravascular papillary endothelial neoplasia. (A) is showing distended vessel (white arrow, H\&E stain, original magnification $\times 10$ ). $(B)$ is showing numerous delicate papillae, consist of endothelial cells lining a hyaline core (white arrow, H\&E stain, original magnification $\times 40)$. (C and D) are showing endothelial cells positive for CD31 (black arrow, original magnification $\times 10, \times 40$, respectively).

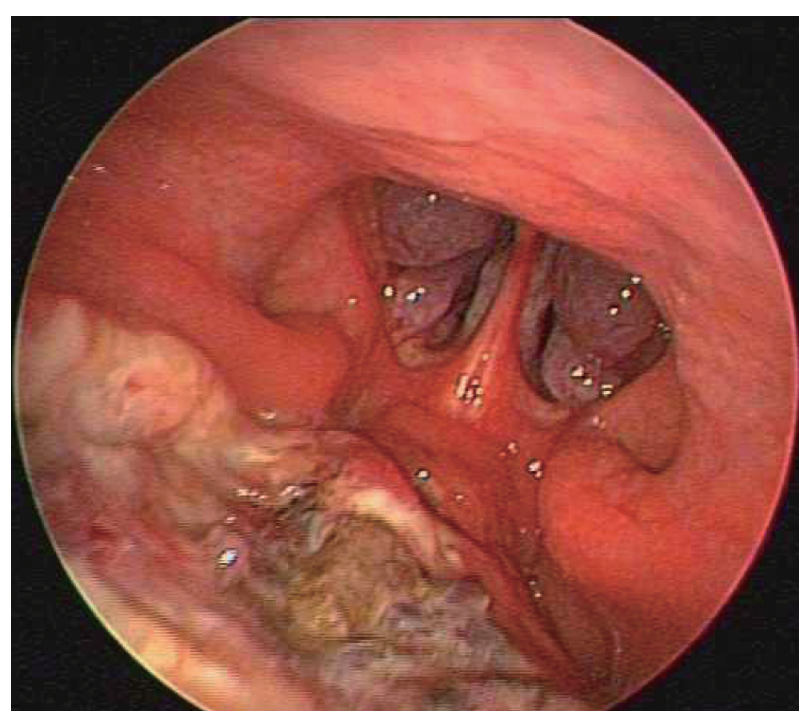

Fig. 5. 70 degree endoscope showing nasopharynx and choana at follow up after 1 week from excision of primary mass.
전신마취 하 병변 제거 직전 바로 시행한 펀치 생검을 통한 조직 검사상 헤마톡실린-에오진 염색(hematoxylineosinstain)에서 유두상으로 보이는 혈관의 팽창 소견과 함께 hyaline core 소견을 관찰할 수 있었으며(Fig. 4A and B), CD31 에 대한 특수 염색을 통해서 혈관 주변으로 위치한 내피 세포 의 증식을 관찰할 수 있었다(Fig. $4 \mathrm{C}$ and D), 이를 통해 유두 상 혈관내막 증식증으로 진단할 수 있었으며, 수술 후 1주 뒤 외래에서 경과 관찰상 비인강 부위 출혈 소견이나 호소하는 불편감 없이 병변 호전된 소견이 관찰되었다(Fig. 5).

\section{고 찰}

유두상 혈관내막 증식증은 1923년 프랑스 병리학자 Mas$\mathrm{son}^{2}$ 에 의해 처음으로 언급된 혈관의 양성 과형성 질환으로 Masson's pseudotumor, Masson's psudoangiosarcoma로도 
일컬어진다. 이름에서 볼 수 있듯이 이는 혈관 육종과 매우 유 사하여 오인하기 쉬운 질환이다. 유두상 혈관내막 증식증은 양성 질환으로 두경부에 광범위하게 발생하거나 주변 주요 조 직을 침범하는 경우가 아닌 국한된 부위에 한정되어 발견된 경우에는 단순 절제로 치료가 가능하지만, 혈관 육종의 경우 에는 병변이 국한되어 나타나더라도 더 근치적인 절제와 함께 절제연에 대해서 술 후 방사선 치료를 요하는 경우가 많기 때 문에, ${ }^{3)}$ 적절한 치료를 위해 유두상 혈관내막 증식증과 정확히 구별하는 것이 중요하다.

유두상 혈관내막 증식증은 전신 어디에서나 발생하는 것 으로 알려져 있으며 여러 부위의 병변이 보고된 바 있다. 두 경부 부위가 제일 흔한 것으로 알려져 있는데 ${ }^{1,4)}$ 그 외에도 입술, 혀, 구강 점막에서도 종종 발견된다. ${ }^{5)}$ 두개내, ${ }^{6}$ 안와 근 처,") 부비동, ${ }^{8)}$ 하비갑개") 등 흔하지 않지만 기타 부위에서도 발견된 것이 보고된 바 있다. 구인두에서 발병한 유두상 혈관 내막 증식증에 대해서는 지금까지 한 차례 보고되었으나,10) 여기서 다루고 있는 비인두에서 발병한 경우는 지금까지 보고 된 바 없는 드문 사례에 해당한다.

이의 병리 기전에 대해서 세 가지가 알려져 있는데 1) 확장 된 혈관에서 새로이 생성되는 원발성, 2) 예전부터 있던 동정 맥 기형, 혈관종, 정맥류 등 병변에 의해 이차적으로 발생하는 이차성(혼합형), 3) 흔하지 않은 형태인 혈관외형으로 나눌 수 있다.1) 본 증례의 경우는 선행하는 혈관 병변이 없으며 혈관 외부도 정상인 상태로 원발성으로 볼 수 있다.

진단을 위해서 우선 육안적으로 검진한 후 영상학적 검사 를 시행할 수 있다. 조영 증강 전산화단층촬영을 할 경우 균 질한(homogenous) 조영 증강, 불균질한(inhomogenous) 조 영 증강을 나타내는 경우가 모두 보고된 바 있는데, ${ }^{1,11}$ 본 증 례에서는 조영 증강 전산화단층촬영 결과 병변이 비인두에 국한되며 주변으로 침윤 소견은 보이지 않는 균질한 조영 증 강 소견이 관찰되었으며, 다른 사례와 유사하게 밖으로 커져 나가는 양상으로 이로 인해 질량 효과(mass effect)를 통해 증상을 나타내게 되었다고 볼 수 있다.111) 전산화단층촬영 외 에 자기공명영상촬영 소견을 시행할 수도 있는데 T1 gadolinum 조영 증강 소견에서 이질성 조영 증강 소견을 보이거나 ${ }^{1)}$ $\mathrm{T} 2$ 조영 증강 소견상 고신호감도 병변이 관찰될 수 있으며, ${ }^{8)}$ 이는 악성 종양으로 오인할 수 있으므로 주의를 요한다. 게다 가 골을 침범해서 들어가는 특성 또한 단순히 영상학적 검사 만으로는 감별 진단을 어렵게 한다.)

따라서 조직학적 검사가 필수적이라고 볼 수 있다. 특징적 인 조직학적 소견으로 혈관 내에 한정된 내막의 증식과 함께 많은 수에서 혈전이 동반된 유두상 구조물이 있다. 그리고 종 괴 내부에 괴사 조직은 발견되지 않으며, 비정형(atypia)은 대
부분 발견되지 않는다. ${ }^{8)}$ 이는 내부에 괴사 조직과 수많은 비 정형을 갖는 혈관 육종하고의 감별점에 있어서 매우 중요한 특성이다. 본 증례의 경우 내피 세포의 증식이 종괴 전체에 걸 쳐 나타나는 혈관 육종과 달리 팽창된 혈관 주변으로만 내피 세포의 증식이 관찰되며, 종괴 내부에 괴사 조직 및 비정형 소견이 관찰되지 않아 혈관 육종을 배제하고 유두상 혈관내 막 증식증으로 진단할 수 있었다.

본 증례에서는 치료 전 조직 검사상 유두상 혈관내막 증 식증으로 진단받은 것은 아니나 약간의 상피 세포 외에 특이 소견이 관찰되지 않아서 양성 혈종 의증 하에 내시경을 통한 병변의 완전 절제를 시행하였다. 이처럼 정확한 진단이 처음 에 밝혀지지 않은 경우라 하더라도 악성으로 진단 내리기 힘 든 상태이거나 혹은 조직 생검상 유두상 혈관내막 증식증으 로 진단되면서, 뇌나 두개골 등 주요 구조물을 침범하지 않는 국한된 병변의 경우 치료는 병변의 단순 절제이다. ${ }^{11)}$ 하지만 뇌 나 두개골 등에 병변이 광범위하게 있는 경우에는 안전연을 포함하여 병변 및 두개 절제술을 시행해야 하며) 완전 절제 가 불가능한 경우에는 술 후 방사선 치료나 항암 치료가 필요 할 수 있다. ${ }^{12)}$ 혈관이 풍부하기 때문에 뇌나 두개골 등 위험 한 부위의 수술 시에는 혈관조영술 혹은 수술 전 색전술이 요 구되나, ${ }^{12)}$ 모든 부위에 대해서 시행하지는 않는다. ${ }^{13)}$ 또한, 불 완전한 절제로 인해 재발한 경우가 보고된 바 있지만, ${ }^{12,13}$ 전 이가 된다는 보고는 없으며 재발한 경우도 병변의 완전 절제 를 목적으로 치료를 시행한다. 본 증례는 외국 노동자의 경 우로 수술 1 주 후 외래에서 경과 관찰 후 특이사항 보이지 않 아 귀국하였으며 그 후의 재발 여부를 확인할 수는 없었다.

조직학적인 진단을 통해서 확진되는 유두상 혈관내막 증 식증은 체내 어디에서나 발생할 수 있으며, 다른 혈관 육종 과 임상적, 영상학적, 조직학적으로 유사한 특성을 가진다. 하지만 특히 조직학적으로 혈관 육종과 구분되는 점을 잘 기 억하여 정확한 진단을 내림으로써 불필요한 과다 치료를 피 하고 단순 절제를 통해 치료하는 것이 무엇보다 중요하다.

\section{REFERENCES}

1) Wang ZH, Hsin CH, Chen SY, Lo CY, Cheng PW. Sinonasal intravascular papillary endothelial hyperplasia successfully treated by endoscopic excision: a case report and review of the literature. Auris Nasus Larynx 2009;36(3):363-6.

2) Masson P. Hemangioendothelioma vegetant intravasculaire. Bull Soc Anat 1923;93:517-23.

3) Abraham JA, Hornicek FJ, Kaufman AM, Harmon DC, Springfield DS, Raskin KA, et al. Treatment and outcome of 82 patients with angiosarcoma. Ann Surg Oncol 2007;14(6):1953-67.

4) Corio RL, Brannon RB, Tarpley TM. Intravascular papillary endothelial hyperplasia of the head and neck. Ear Nose Throat J 1982; 61:88-91.

5) Soares AB, Altemani A, Furuse C, Demasi AP, Gati C, Nunes N, et al. Intravascular papillary endothelial hyperplasia: report of 2 cases 
and immunohistochemical study. Oral Surg Oral Med Oral Pathol Oral Radiol Endod 2008;106(5):708-11.

6) Lee SK, Jung TY, Baek HJ, Kim SK. Destructive radiologic development of intravascular papillary endothelial hyperplasia on skull bone. J Korean Neurosurg Soc 2012;52(1):48-51.

7) Werner MS, Hornblass A, Reifler DM, Dresner SC, Harrison W. Intravascular papillary endothelial hyperplasia: collection of four cases and a review of the literature. Ophthal Plast Reconstr Surg 1997;13(1):48-56.

8) Moon WS, Chung GH, Hong KH. Intravascular papillary endothelial hyperplasia in a vascular lesion of the paranasal sinus. Arch Pathol Lab Med 2000;124(8):1224-7.

9) Lee JH, Lee SH, Jeong HM, Yun KJ. A case of intravascular papillary endotheliel hyperplasia of inferior turbinate. Korean J OtolaryngolHead Neck Surg 2005;48(9):1189-92.
10) Ejeckam GC, Orizaga M, Gerin-Lajoie J, Castilio G. Intravascular angiomatosis of the pharynx (Masson's vegetant intravascular haemangioendothelioma)--a case report. Br J Oral Surg 1978;16(2): 105-10.

11) Pantanowitz L, Muc R, Spanger M, Sonnendecker H, McIntosh WA. Intravascular papillary endothelial hyperplasia (Masson's tumor) manifesting as a lateral neck mass. Ear Nose Throat J 2000;79(10): 806, 809-10, 812 passim.

12) Avellino AM, Grant GA, Harris AB, Wallace SK, Shaw CM. Recurrent intracranial Masson's vegetant intravascular hemangioendothelioma. Case report and review of the literature. J Neurosurg 1999;91(2): 308-12.

13) Safneck JR, Alguacil-Garcia A, Dort JC. Intranasal papillary endothelial hyperplasia. Otolaryngol Head Neck Surg 1995;113(6): 766-70. 